\title{
The Ottawa Field-Naturalists' Club Awards for 2008
}

\author{
Irwin M. Brodo, Christine Hanrahan, Diane Lepage, and Eleanor ZurbrigG
}

On 25 April 2009, members and friends of the Ottawa Field-Naturalists' Club (OFNC) gathered at the Club's annual Soirée at St. Basil's Church in Ottawa, and once again, awards were given to members and one nonmember who distinguished themselves by accomplishments in the field of natural history and conservation

\section{Christine Hanrahan - Honorary Member}

This award is presented in recognition of outstanding contributions by a member or non-member to Canadian natural history or to the successful operation of the Club. Usually people awarded an honorary membership have made extensive contributions over many years.

Christine Hanrahan could be receiving this award to honour over two decades' worth of dedicated investigation and documentation of the flora and fauna in natural areas in Ontario and British Columbia or for countless hours of footslogging on personal bioblitzes, which have added to the knowledge of the natural history of such places as Colony Farm, DeBoville Slough, Burke Mountain, and Douglas Island in British Columbia and Petrie Island, Larose Forest, and the Fletcher Wildlife Garden (FWG) in our local area.

Christine could also be receiving this award as a writer for her outstanding contributions in education. Web articles and brochures, such as "How to Get Started in Birdwatching?", "Creating a Safe Garden for Birds," "Trees and Shrubs for Birds," "Wildflowers of the Fletcher Wildlife Garden," and "The Ruddy Duck in Eastern Ontario" are a few examples. She is also a major contributor to Trail \& Landscape, writing the regular Fletcher Wildlife Garden updates, reports from the Ontario Breeding Bird Atlas project, and a series of articles on small mammals. In more than 25 years of contributions, Christine has had over 60 articles published in Trail \& Landscape. In recent years, the OFNC website cannot be visited without seeing Christine's contributions: from the home page photo to general interest articles, species lists, the FWG Blog, Larose Forest reports, and her latest project, the PBase photo galleries.

\section{Diane Lepage - Member of the Year}

The OFNC's Member of the Year award recognizes the member judged to have contributed the most to the Club in the previous year. Diane Lepage is the 2008 Member of the Year for her dedicated work as a volunteer at the Fletcher Wildlife Garden (FWG).

Diane, who has been an OFNC member since 1980, joined the FWG Management Committee in 2004 and almost immediately became an integral part of the or by extraordinary activity within the Club. Careful observation of plants and animals, political savvy, selfless service, and teaching skills are all in evidence among the 2008 winners. The following citations for those who received an award were read to the members and guests assembled for the event.

This award might also be given for longstanding Club service in committee work. Christine has worked long hours with committees of the OFNC and other natureoriented organizations. Always an effective and committed committee member, Christine has served on the Birds, FWG Management, Conservation, and Awards committees. Where did Christine find the time for nonClub activities like being Regional Coordinator for the First (1983-1986) and Second (2000-2005) Ontario Breeding Bird Atlases for the Ottawa region with a team of 120 volunteers, checking and verifying data, and writing final reports? Annually Christine helps organize the Wildlife Festival, a major event with multiple activities attracting large public participation. Christine's name will always be associated with the Larose Forest, a special place for her, where she currently represents the OFNC on the Larose Forest Advisory Committee and in 2008 chaired the Larose Forest 80th Anniversary celebrations. There are many, many other activities which benefit from Christine's organization, support, and leadership.

Christine Hanrahan is receiving this award-an honorary membership in the Club-to recognize and acknowledge the astonishing depth of her love and caring for everything natural and the efforts she has undertaken to make people "see the beauty and the wonder of even the tiniest creature or plant." She has taken almost every opportunity one can imagine to promote the interest of the public in natural history, believing that the more people learn about a species or habitat, the more respect they will have for it and be willing to protect it. Christine is truly an amazing field-naturalist.

FWG group. For some years, the FWG committee had debated whether it was worthwhile continuing to maintain the butterfly meadow. The task seemed quite overwhelming and so no decision either way was made until Diane arrived. She saw the potential for rejuvenating the existing site as well as creating a new addition to the meadow. During preliminary visits to the site, she was impressed by the number of butterflies and other 
insects she found, and was more than ever resolved to undertake some serious work there. She drafted plans for the site, including lists of plants, and gave them to the committee for input. By 2006 she had rounded up a dedicated team of volunteers who come every Wednesday evening from spring to mid-September. However, it was during 2008 that Diane redoubled her efforts, and there was a remarkable transformation of the new section of the meadow into a place of flourishing blooms where insects are abundant until late fall. Early in 2008, she arranged for further roto-tilling of the area, after which she and her team removed the invasive Dogstrangling Vine, as they had done in previous years, preparing the site for more planting. Plans for 2009 are ambitious and include more roto-tilling, more Dogstrangling Vine control, and planting for nectar and for larval food. She also plans to continue work on rejuvenating the old butterfly meadow by carrying on with intensive Dog-strangling Vine removal, control of Sumacs (which are invading the meadow), and of course, more planting.

Diane's involvement with the Fletcher Wildlife Garden is not confined to the butterfly meadow. As noted, she is an important member of the FWG Management Committee. She continues to help with invasive plant removal from the amphibian pond; maintains the binder of FWG minutes, making sure we have a complete set of these minutes available; prints the FWG brochures and information sheets; maintains the FWG library; and leads walks.

For all of these reasons, and with a focus on achievements in 2008, we believe that Diane is a fitting recipient of the 2008 Member of the Year Award.

\section{Phillip Jeffreys - George McGee Service Award}

The OFNC George McGee Service Award is given in recognition of a member who has contributed significantly to the smooth running of the Club over several years.

Phil Jeffreys has been an active member of the Excursions and Lectures Committee for a number of years and has made valuable contributions to the work of the committee. Seven years ago, Phil volunteered to seek a new location for our annual Soirée, eventually choosing the convenient and affordable St. Basil's Church. Since then Phil has taken charge of the general arrangements for the Soirée at this venue, working out a convenient floor plan, setting up and taking down exhibit structures, and designing and constructing several components in his workshop that facilitate this process and that add to the aesthetics of the scheme. Phil is responsible for phoning potential exhibitors to ensure meaningful participation from Club members, and he organizes a cadre of capable people to help. He is our liaison with St. Basil's, booking the hall each year, arranging for the sound equipment, and renting the dishes so that we can all enjoy a very festive occasion.

Phil has also taken on the responsibility of hiring buses for our longer trips, such as the spring birding trip to Point Pelee, and for making our hotel bookings. He never fails to check, and double-check, with the hotels and bus companies to make sure that all arrangements are in place, and he sees to the comfort of all the participants.

Many thoughtful ideas and suggestions for improving and adding to Club events and for enhancing the Club's profile in the community in general have also come from Phil in his capacity as a member of the Excursions and Lectures Committee.

For these reasons and more, we wish to honour Phillip Jeffreys with the George McGee Service Award for 2008 .

\section{Kenneth W. McRae - Conservation Award (Non-member)}

The Conservation Award for a non-member is given in recognition of an outstanding contribution by a nonmember to the cause of natural history conservation in the Ottawa Valley, with particular emphasis on activities within the Ottawa District.

Ken McRae is the recipient of the 2008 award to recognize his exceptional efforts as a champion of water resources, concentrating on wetlands in the Ottawa area while also monitoring other issues in eastern Ontario and in provincial legislation. Ken is extremely hardworking and dedicated, and he has become very knowledgeable about wetland protection and related development issues. All of this work has been done as a volunteer while holding down a full-time job.

Ken identifies problems primarily by monitoring the Ontario Environmental Registry, where all environ- mental changes requiring government approval are posted, such as permits to remove water or amendments to municipal zoning by-laws. The problems that Ken so identifies are then researched exhaustively, and detailed briefs are presented to appropriate authorities and followed up diligently. Some issues go on for many years, making it difficult for any one person to continue to address them, but Ken persists with fortitude.

Copies of his correspondence are circulated to a large number of people interested in protecting wetlandswhich may include local politicians and government staff_-alerting them to possible negative effects of planned activities. This information serves to raise or enhance awareness and to facilitate participation in decision making regarding management of our environment. Ken's actions serve as a model to residents of 
Ontario to exercise their rights under the Environmental Bill of Rights and help to improve government decision making on the environment.

Lately Ken has focused on preserving Ottawa's Goulbourn Wetland Complex, on permits to take water that have an impact on wetlands such as the Leitrim wetland, and on environmental issues pertaining to quarries and golf courses. Other issues that Ken has grappled with include the class environmental assessment for the Highway 7 expansion, the treatment of provincially wetlands under the City of Ottawa Official Plan, and drainage issues under the Drainage Act. In past years, he served as a member of the Friends of the Jock River.

Ken McRae is a worthy recipient of the Conservation Award (non-member) for 2008. Congratulations!

\section{Stanley D. Rosenbaum - Conservation Award (Member)}

The Conservation Award for Members is presented in recognition of an outstanding contribution by a member of the OFNC in the cause of natural history conservation in the Ottawa Valley, with particular emphasis on activities within the Ottawa District. Stan Rosenbaum is chosen as the recipient for 2008 in recognition of his long and dedicated service to the smooth running of the Conservation Committee.

Stan really is the public face of conservation for the OFNC and has been for many years. He won this same award in 1999 for his work in turning around the Conservation Committee, which was undergoing a crisis of confidence at that time. Now we believe that his remarkable contribution to conservation deserves to be recognized again. Stan is the guiding light of the Conservation Committee, and without him at the helm, many issues would not be addressed.

A long-time member of both the OFNC and the Canadian Parks and Wilderness Society, and closely involved with the Greenspace Alliance, Stan has been interested in the outdoors for many decades. When he retired he decided that it was time to devote more energy and time to the protection of our natural areas. The issues that he has been involved with over the last 12 years are numerous.

On behalf of the OFNC Conservation Committee, Stan has written countless letters to all levels of government, on a wide variety of issues. Topics include the quarry proposal for 5309 Bank St. (the old South Gloucester conservation area); Leitrim Wetlands; support for a campaign to ban cosmetic use of pesticides; Provincial Planning Reform; protection of the Carden Alvar and the Braeside Alvar; the issue of development in Gatineau Park; Bill 184 (Ontario's Endangered Species Act, 2007) — the list goes on and on. These letters take considerable research and time to prepare, and the facts and arguments are checked, and then checked again, and checked once more, before they are sent. Thanks to Stan, the credibility of the OFNC on conservation matters continues to be maintained.

Stan has also attended innumerable open houses on issues ranging from expansion of the Nortel property into the National Capital Commission greenbelt, Lands for Life, Ontario Parks legislation review, South March Highlands management plan, and Planning Act regulations, to name only a few of the many.

In 2008, Stan led the OFNC's objection to the White Paper released by the City of Ottawa to test public reaction to developing parts of the greenbelt; the City withdrew the paper.

As if all of this is not enough, Stan has represented the OFNC on many coalitions and working groups. These include, but are not limited to, the Light Rail Maintenance Yard Public Working Group, the NCC Renewal Coalition, the Gatineau Park Protection Coalition, and the Greenbelt Coalition.

In addition to the above-mentioned letters, Stan frequently prepares well-researched briefs presenting the conservation point of view on many of the above issues.

Additionally, when the call went out from the Ontario Ministry of Natural Resources in 2008 for help in eastern Ontario with a hands-on project to remove the invasive Water Chestnut, Stan was right there. He not only helped find volunteers, but volunteered for field work himself.

Stan not only chairs the Conservation Committee, he also serves as committee secretary, preparing the agenda beforehand and the minutes afterwards. These excellent summaries are used to prepare the quarterly Conservation Matters articles for Trail \& Landscape. Stan also writes annual reports on committee activities for the OFNC Council and brings important issues to Council's attention. In other words, Stan is tireless in his pursuit of fair play for conservation issues.

For all of these reasons and more, Stan Rosenbaum is a fitting recipient of the 2008 Conservation Award (Member).

\section{Robert E. Lee - Mary Stuart Education Award}

The Mary Stuart Education Award was established to recognize members, non-members, or organizations for their outstanding achievements in the field of natural history education in the Ottawa Region.

Selecting a recipient for this year's Mary Stuart Education Award was not difficult, because he was not far away. The award goes to our own Rob Lee, leader of the OFNC's junior branch-the Macoun Field Club-for the past 16 years. This award is not just for being the leader, certainly worthy of an award in itself, but for having such an extraordinary ability to teach natural history and to inspire young people. Rob is first 
and foremost an innovative educator who for decades has shown members of the Macoun Field Club how to observe and learn for themselves, how to figure out what they are seeing, and how to be resourceful in their pursuit of knowledge. Rob and his students sometimes do extraordinary things. He recently had them dig through ant nests looking for (and finding!) a rare species of aphid. Why would he do this? Because Rob himself is curious about the ants and the aphid farming they do, and he shares this enthusiasm for learning and curiosity about the natural world with the Macoun Club members. We wonder whether the parents of the Macoun kids realize what a treasure has been made available to them through the Club. Rob encourages Macoun Club members to talk about their discoveries, giving them priceless experience in speaking in front of a crowd, and he encourages them to write up their results for the Club's publication, The Little Bear, giving them experience in scientific writing. They participate in Rob's web page, giving them an opportunity to learn about the use of computers in sharing information and researching subjects. He leads them to appropriate books in the Macoun Club's own library, instilling a love of literature. The rich world of natural history that Rob introduces to his charges will always remain with them, no matter where their lives take them. Rob Lee is a teacher to be watched and to be emulated, and for this, the OFNC is very pleased to award him the 2008 Mary Stuart Education Award. Wouldn't Mary have been delighted!

\section{Otto Loesel - Anne Hanes Natural History Award}

The Anne Hanes Natural History Award is given in recognition of a member who, through independent study or investigation, has made a worthwhile contribution to our knowledge, understanding, and appreciation of the natural history of the Ottawa Valley.

Otto Loesel is the recipient of this award for 2008, recognizing his years of independent study of woodrotting fungi (Polyporales) in the National Capital Region and in particular in Gatineau Park. Otto has a long-standing passionate interest in nature and a love of learning and teaching about the polypore fungi, on which he is a self-taught expert.

Otto has spent a large amount of time exploring and inventorying the fungi (mycoflora) of Gatineau Park. Based on numerous field trips to different areas and habitats in the Park, he developed a list of 106 species of fungi. Significantly, Otto recorded specimens of an unusual polypore (wood-rotting fungus that grows on snags and fallen tree trunks) in the Ottawa region 11 times, and later at 39 locations in Gatineau Park and the National Capital Commission greenbelt, and one at Larose Forest. Otto checked with experts, and it became evident that this unusual polypore was Trametes gibbosa, a species commonly found in Europe and recently introduced in North America. Otto's specimens were the first recorded for Canada. Otto published an article in the September 2008 volume of Trail \& Landscape on his discovery of Trametes gibbosa.

Otto is keen to share his knowledge of fungi, and last year he took the Macoun Field Club on a mushroom identification foray to identify species such as bracket fungi and crust fungi. He has also led walks to see the polypores of Gatineau Park. His depth of knowledge of fungi was beautifully demonstrated at one of the Tuesday evening OFNC monthly meetings when the scheduled speaker couldn't make it. Otto volunteered to give an impromptu talk on fungi, and it was fascinating from beginning to end. Otto also gave generously of his time in order to give two informal workshops on polypores at the Fletcher Wildlife Garden at which participants brought photos of unidentified polypores, which he then helped them to identify and explained what they were. The workshops were tremendously interesting and an indication of how much Otto is willing to help anyone who shows a keen interest in learning more about polypores.

Otto is a member of the Mycologues amateurs de l'Outaouais (amateur mycologists), and he contributes photos of fungi to an Internet site. In 2006, he participated as a mushrooms (mycology) contributor to the 2006 BioBlitz in the Larose Forest.

We are delighted to present the Anne Hanes Natural History Award to Otto Loesel. 